\title{
Regulation of the neuroendocrine reproductive axis by kisspeptin-GPR54 signaling
}

\author{
Jeremy T Smith ${ }^{1}$, Donald K Clifton ${ }^{2}$ and Robert A Steiner ${ }^{1,2}$ \\ Departments of ${ }^{1}$ Physiology and Biophysics and ${ }^{2}$ Obstetrics and Gynecology, University of Washington, Seattle, \\ Washington 98195-7290, USA \\ Correspondence should be addressed to R A Steiner at Department of Physiology and Biophysics, Health Sciences Building, \\ G-424, School of Medicine, University of Washington, Box no. 357290, Seattle, WA 98195-7290, USA; \\ Email: steiner@u.washington.edu
}

\begin{abstract}
The Kiss1 gene codes for a family of peptides that act as endogenous ligands for the G protein-coupled receptor GPR54. Spontaneous mutations or targeted deletions of GPR54 in man and mice produce hypogonadotropic hypogonadism and infertility. Centrally administered kisspeptins stimulate gonadotropin secretion by acting directly on GnRH neurons. Sex steroids regulate the expression of KiSS-1 mRNA in the brain through direct action on KiSS-1 neurons. In the arcuate nucleus (Arc), sex steroids inhibit the expression of KiSS-1, suggesting that these neurons serve as a conduit for the negative feedback regulation of gonadotropin secretion. In the anteroventral periventricular nucleus (AVPV), sex steroids induce the expression of KiSS-1, implying that KiSS-1 neurons in this region may have a role in the preovulatory LH surge (in the female) or sexual behavior (in the male).

Reproduction (2006) 131 623-630
\end{abstract}

\section{Discovery}

GPR54 is a G protein-coupled receptor, which was originally identified as an 'orphan' receptor in the rat (Lee et al. 1999). Although GPR54 shares a modest sequence homology with the known galanin receptors, galanin apparently does not bind specifically to this receptor (Lee et al. 1999). In 2001, three teams of investigators discovered in quick succession that the natural ligand for GPR54 is a 54-amino-acid product of a gene called Kiss1 (Kotani et al. 2001, Muir et al. 2001, Ohtaki et al. 2001). The Kiss 1 gene was originally isolated as a tumor metastasis gene, and the peptide product was named metastin, reflecting its ability to suppress metastasis of melanomas (Lee et al. 1996). (In this review, the term 'kisspeptin' will refer to metastin and other biologically active fragments of metastin.) In 2003, two independent groups discovered almost simultaneously that disabling mutations of GPR54 are associated with a failure to progress through puberty and hypogonadotropic hypogonadism in man (de Roux et al. 2003, Seminara et al. 2003). This observation was corroborated by studies of mice bearing targeted deletions of GPR54, where it was noted that reproductive dysfunction is apparently the only remarkable phenotypic anomaly associated with the mutation (Funes et al. 2003, Seminara et al. 2003). Thus, kisspeptin-GPR54 signaling is essential to initiate gonadotropin secretion at puberty and support reproductive function in the adult.

\section{How Kiss1 got its name}

Investigators at the Pennsylvania State College of Medicine in Hershey, Pennsylvania, discovered the Kiss1 gene. To associate the discovery with their hometown and its most famous product - the Hershey chocolate Kiss - and to incorporate the letters 'SS' (referring to 'suppresser sequence'), the scientists named the gene KiSS-1. By the 'Rules for Nomenclature of Genes, Genetic Markers, Alleles, and Mutations in Mouse and Rat', the authorities at the Mouse Genome Informatics renamed the gene Kiss1. However, the revised nomenclature has not yet been widely adopted. In this review, we will refer to the gene as Kiss 1 and the messenger RNA as KiSS-1 mRNA, in keeping with current usage.

\section{Kisspeptins stimulate gonadotropin-releasing hormone (GnRH)}

Several groups have now shown that kisspeptin, administered either centrally or peripherally, stimulates gonadotropin secretion. Gottsch et al. (2004) reported that extraordinarily low doses of kisspeptin $(\sim 1 \mathrm{fmol})$, injected 
into the lateral ventricle of the mouse, can elicit a rapid and robust secretory burst of luteinizing hormone (LH) and follicle-stimulating hormone (FSH). Similar observations (but with higher doses of kisspeptin) were reported in the rat (Matsui et al. 2004, Navarro et al. 2004a, 2005), sheep (Messager et al. 2005), monkey (Shahab et al. 2005, Plant et al. 2006) and, most recently, the human male (Dhillo et al. 2005). In addition to corroborating the observation that kisspeptin stimulates gonadotropin secretion, these latter studies also demonstrated that the effect of kisspeptin on circulating levels of LH is unusually prolonged - far beyond that which would have been produced by centrally administered secretagogues, such as N-methyl-D-aspartate (NMDA) (Saitoh et al. 1991, Navarro et al. 2004a, 2005). Moreover, as demonstrated in the mouse, rat, and monkey, the GnRH antagonist acyline can block the kisspeptin-induced release of $\mathrm{LH}$ and $\mathrm{FSH}$ (Gottsch et al. 2004, Irwig et al. 2004, Shahab et al. 2005). This suggests that kisspeptin-stimulated gonadotropin release is dependent on the release of $\mathrm{GnRH}$ and does not reflect a direct action of kisspeptin on the pituitary. The apparent lack of kisspeptin's effect on the pituitary was confirmed in the rat by Matsui et al. (2004), who reported that another $\mathrm{GnRH}$ antagonist, cetrorelix, also blocks the kisspeptin-induced release of $\mathrm{LH}$ and $\mathrm{FSH}$. However, in vitro, kisspeptin has been shown to stimulate $\mathrm{LH}$ release and augment $\mathrm{GnRH}$-stimulated $\mathrm{FSH}$ release from pituitary explants derived from peripubertal male rats - albeit modestly (Navarro et al. 2005a, 2005b); nevertheless, kisspeptin has little or no effect on the release of either LH or FSH from primary cultures of pituitary cells derived from rats (Matsui et al. 2004). Moreover, another study reports that kisspeptin has no effect on $\mathrm{LH}$ and $\mathrm{FSH}$ release from rat pituitary explants, yet it stimulates $\mathrm{GnRH}$ secretion from hypothalamic explants (Thompson et al. 2004). The concept that kisspeptin can activate GnRH neurons in the forebrain is buttressed by reports that kisspeptin induces expression of the immediate early gene product Fos in GnRH neurons in the rat (Irwig et al. 2004, Matsui et al. 2004). Furthermore, infusion of kisspeptin into the third ventricle of sheep increases levels of $\mathrm{GnRH}$ found in the cerebrospinal fluid (Messager et al. 2005). Despite compelling evidence that kisspeptins act directly on the hypothalamus to induce gonadotropin release, GPR54 is expressed in the pituitary (Kotani et al. 2001, Muir et al. 2001). Thus, further experiments are necessary to determine whether kisspeptin-GPR54 signaling in the pituitary plays a role in the regulation of either gonadotropin or other pituitary hormone secretion.

Kisspeptin-expressing neurons are localized in discrete regions of the forebrain. Early reports indicated that transcripts for KiSS-1 mRNA are detectable by RT-PCR in the human brain (Muir et al. 2001). Gottsch et al. (2004) mapped the location of cells expressing KiSS-1 mRNA in the mouse by in situ hybridization. They found that KiSS-1 mRNA is expressed in cells that reside in the anteroventral periventricular nucleus (AVPV), the periventricular nucleus (PeN), the anterodorsal preoptic nucleus (ADP) and the arcuate nucleus (Arc) (Gottsch et al. 2004, Smith et al. 2005a,b) (Fig. 1). Studies in the rat by immunocytochemistry have yielded mixed results. An initial report suggested that kisspeptin-containing cell bodies may be located in the dorsomedial hypothalamic nucleus, nucleus of the solitary tract, and the caudal ventrolateral medulla, with only scattered positive cells in the PeN and Arc (Brailoiu et al. 2005); however, a second published report testifies to observing kisspeptin-containing cell bodies only in the Arc (Kinoshita et al. 2005). Additional studies
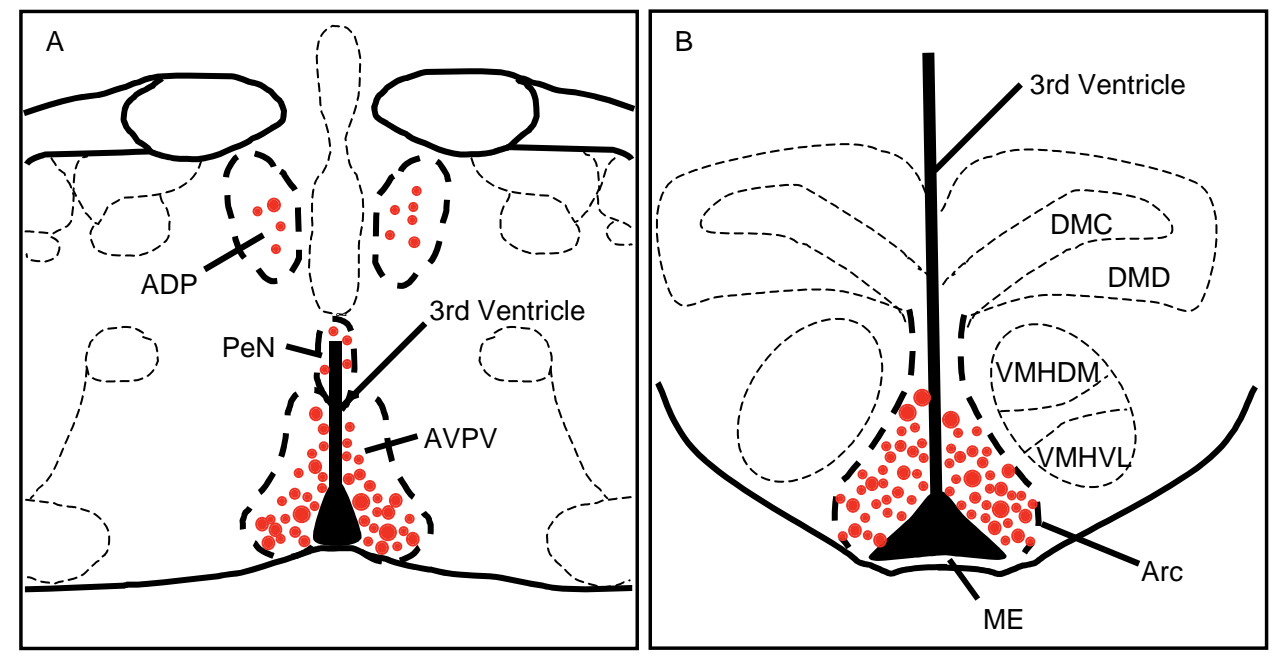

Figure 1 Localization of KiSS-1 mRNA in the forebrain of the mouse. Each panel depicts a hypothalamic section. Panel A is most rostral and shows KiSS-1 mRNA localization (red dots) in the anteroventral periventricular nucleus (AVPV), periventricular nucleus (PeN) and anterodorsal preoptic area (ADP). Panel B is more caudal and shows KiSS-1 mRNA localization in the arcuate nucleus (Arc). DMC: dorsomedial hypothalamus (compact); DMD: dorsomedial hypothalamus (diffuse); ME: median eminence; VMHDM: ventromedial hypothalamus (dorsomedial); VMHVL: ventromedial hypothalamus (ventrolateral). 
with other, better antisera to kisspeptin will be required to clarify this matter.

Kisspeptin appears to act directly on GnRH neurons to stimulate the secretion of $\mathrm{GnRH}$. Areas where kisspeptin neurons reside, such as the Arc and AVPV, are known to send projections to the medial preoptic area, where there is an abundance of $\mathrm{GnRH}$ cell bodies (Canteras et al. 1994, Simonian et al. 1999). Kisspeptin-containing fibers project to these same areas (Brailoiu et al. 2005), and indeed, kisspeptin fibers appear in close approximation to GnRH neurons (Kinoshita et al. 2005). If kisspeptin neurons communicate directly with GnRH neurons, one would expect GnRH neurons to express GPR54. Parhar et al. (2004) isolated GnRH neurons from the cichlid fish Oreochromis niloticus by laser capture microscopy and identified GPR54 mRNA transcripts in these cells by realtime quantitative RT-PCR. They found that approximately $50 \%$ of $\mathrm{GnRH}$ neurons in these animals coexpress GPR54. In the rat, Irwig et al. (2004) used double-label in situ hybridization to show that the majority $(>75 \%)$ of GnRH neurons in this species also coexpress GPR54 mRNA; subsequently, it was shown that in the mouse approximately $50 \%$ of GnRH neurons express GPR54 (Messager et al. 2005). Our own studies in the mouse with high-resolution in situ hybridization suggest that the percentage of GnRH neurons coexpressing GPR54 in this species may be even greater (Han et al. 2005). The relatively high degree of GPR54/GnRH coexpression is similar to the fraction of GnRH neurons that express Fos after central administration of kisspeptin (Irwig et al. 2004, Matsui et al. 2004). Thus, kisspeptin appears to act directly on GnRH neurons to stimulate GnRH secretion (Fig. 2). In addition, GPR54 appears to be the only functional receptor for kisspeptins - at least in the context of gonadotropin secretion - since kisspeptin has no effect on LH or FSH secretion in mice that lack a functional GPR54 (Messager et al. 2005). Although these observations clearly establish the ability of kisspeptin-GPR54-GnRH signaling to activate $\mathrm{LH}$ and $\mathrm{FSH}$ secretion under experimental conditions, they provide little insight into kisspeptin's functional significance.

\section{Steroids regulate kisspeptins}

Gonadal activity - including hormone production and gametogenesis - is regulated by the brain and pituitary, which are both targets for the feedback control of gonadotropin secretion by sex steroids. Although $\mathrm{GnRH}$ neurons appear to express the estrogen receptor $\beta$ (ERß) (Hrabovszky et al. 2000, 2001), it is widely believed that other steroid-responsive neurons in the forebrain mediate the predominant actions of estrogen and androgen in the regulation of $\mathrm{GnRH}$ and gonadotropin secretion (Herbison 1998). ER $\alpha$ and $E R \beta$, as well as the androgen receptor (AR), are expressed in the periventricular regions of the forebrain where kisspeptin

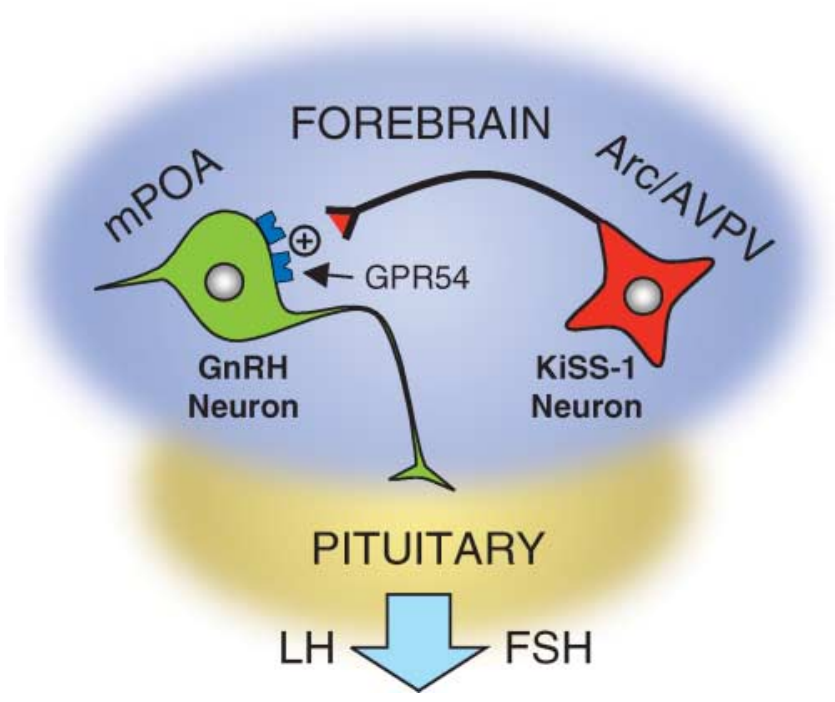

Figure 2 Proposed interactions between kisspeptin-secreting neurons and GnRH neurons. In this model, KiSS-1 mRNA-expressing neurons, from the arcuate nucleus (Arc) and the anteroventral periventricular nucleus (AVPV), make synaptic contact with GnRH neurons within the preoptic area (POA). Upon activation of the kisspeptin receptor GPR54, GnRH neurons are stimulated to release GnRH into the portal circulation, which in turn stimulates the release of gonadotropins, luteinizing hormone ( $\mathrm{LH}$ ) and follicle-stimulating hormone (FSH), from the pituitary.

neurons reside (Simerly et al. 1990, Hagihara et al. 1992, Shughrue et al. 1997). The phenotypic identity of cells that receive input from gonadal steroids and relay this information to $\mathrm{GnRH}$ neurons remains unknown; however, kisspeptin neurons seem poised to play this role. Measurements by RT-PCR reveal that total hypothalamic content of KiSS-1 mRNA increases significantly after gonadectomy and decreases with sex steroid replacement (Navarro et al. 2004a). However, a detailed, regional analysis of KiSS-1 mRNA in the forebrain of mice by in situ hybridization has produced a more complex picture. In the Arc, manipulations of the sex steroid milieu by castration and sex steroid replacement produce the same outcome as reflected by RT-PCR measurements - an increase in KiSS-1 mRNA after castration and decline with steroid treatment. However, in the AVPV and PeN, the opposite occurs in both sexes - a decline in the expression of KiSS-1 mRNA with castration and an increase in expression with sex steroid replacement (Smith et al. 2005a, 2005b) (Fig. 3). Thus, the activity of kisspeptin neurons in the Arc is stimulated by gonadectomy and inhibited by sex steroids. If kisspeptin neurons in the Arc provide tonic facilitatory input to $\mathrm{GnRH}$ neurons, it seems plausible that kisspeptin neurons could mediate the negative feedback effects of steroids on GnRH secretion, activating $\mathrm{GnRH}$ neurons when plasma levels of sex steroids decline and inhibiting GnRH neurons when sex steroids rise. 
AVPV

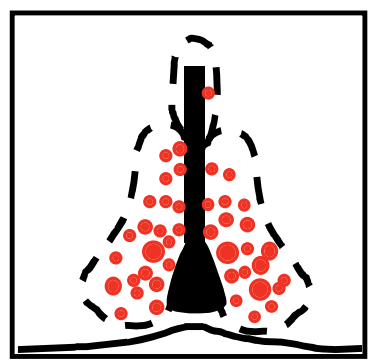

Intact

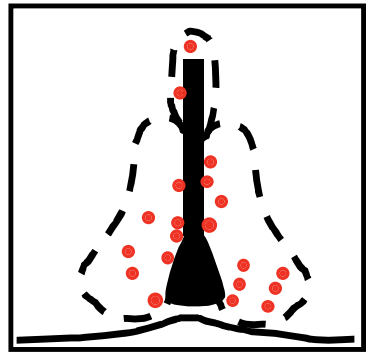

OVX

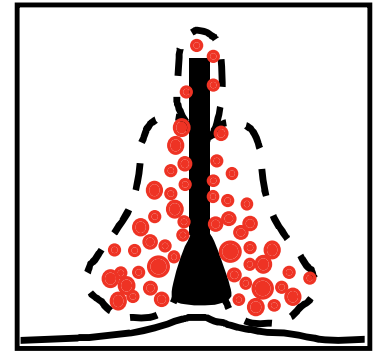

$\mathrm{OVX}+\mathrm{E}$

AVPV

KiSS-1 Neuron

Arc

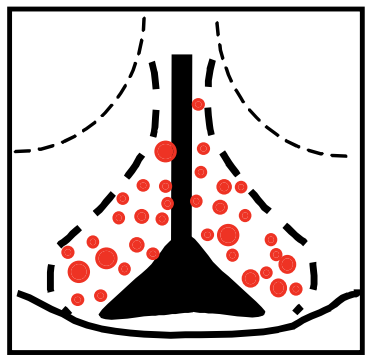

Intact

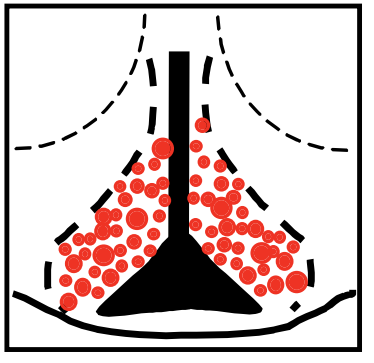

OVX

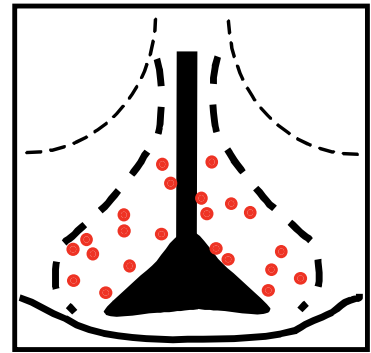

$\mathrm{OVX}+\mathrm{E}$

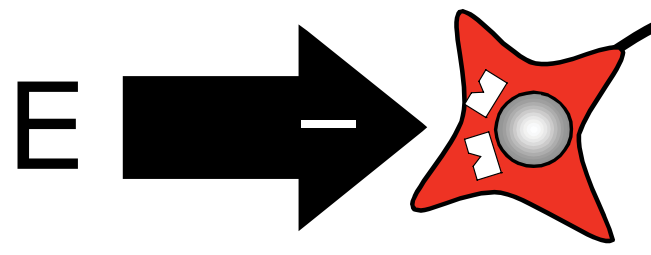

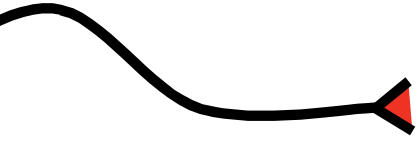

Arc
KiSS-1 Neuron
Figure 3 KiSS- 1 mRNA is differentially regulated by estrogen in the forebrain of the mouse. The upper panel depicts the expression of KiSS-1 mRNA (red dots) in the anteroventral periventricular nucleus (AVPV) of the female diestrus (intact), ovariectomized (OVX), and OVX-estradiol replaced $(+\mathrm{E})$ mouse. The diagram illustrates the apparently positive ( + ve) regulation of KiSS- 1 mRNA by E in the AVPV. The lower panel depicts the expression of KiSS-1 mRNA in the arcuate nucleus (Arc) of the female diestrus (intact), OVX and OVX + E mouse. The diagram illustrates the apparently negative $(-$ ve) regulation of KiSS- 1 mRNA by $E$ in the Arc.
The KiSS-1 neurons that reside in the AVPV clearly behave differently from those in the Arc; hence, KiSS-1 neurons in this region would appear to serve a different physiologic function. The AVPV is one of the few sexually dimorphic areas of the forebrain that is larger in the female than the male (Simerly 1998), and in this region there are many more KiSS-1 neurons in the female than the male (Smith et al. 2005a,b). The AVPV has been implicated in the generation of the preovulatory $\mathrm{GnRH} / \mathrm{LH}$ surge in the female (Gu \& Simerly 1997). The phenotypic identity of neurons in the AVPV that help to orchestrate the surge is unknown, but kisspeptin neurons could conceivably serve this function. Sex steroids induce the expression of KiSS-1 in the AVPV, and it seems plausible that this activational event drives the GnRH/LH surge. Indeed, central administration of an 'antikisspeptin' antibody blocks the LH surge at proestrus in the rat (Kinoshita et al. 2005), indicating that kisspeptin is essential for generating the preovulatory LH surge. This interpretation would not rule out a contribution by KiSS-1 neurons in the Arc, which apparently show an increase in peptide and Fos expression (detected by immunocytochemistry) at the time of proestrus (Kinoshita et al. 2005). Further studies are required to clarify the potential role of kisspeptin neurons in the AVPV and Arc in generating the preovulatory GnRH/LH surge.

The involvement of gonadal steroids in the regulation of kisspeptin neuronal activity suggests that either kisspeptin neurons express steroid receptors or they receive input about circulating steroid levels from other steroid-sensitive neurons. Smith et al. (2005b) showed that cells expressing KiSS-1 mRNA also express sex steroid receptors. In male mice, more than $60 \%$ of KiSS-1 neurons in the Arc express AR and about 90\% express 
the ER $\alpha$. In the female mouse, nearly all KiSS-1 neurons express ER $\alpha$, and approximately 30\% express ER $\beta$ (Smith et al. 2005a). Thus, KiSS-1 neurons are direct targets for the action of sex steroids in both the male and female mouse.

Although it is reasonable to assume that the effects of estrogens on kisspeptin neurons are mediated by ER, testosterone can either act directly through AR or indirectly through ER after its aromatization to estradiol. To determine which steroid receptors are actively involved in the regulation of kisspeptins in the male, Smith et al. (2005b) examined the effects of estradiol and dihydrotestosterone (DHT), a nonaromatizable androgen, on the expression of KiSS-1 mRNA in castrated male mice. Estradiol mirrored the effect of testosterone in both the Arc and AVPV, whereas DHT had an effect only in the Arc. This would suggest that both AR and ER play a role in the regulation of KiSS-1 expression in the Arc, but that the ER mediates the effects of testosterone on KiSS-1 regulation in the AVPV. For further clarification of the role of the sex steroid receptors in the regulation of KiSS- 1 mRNA, the effect of steroid hormone treatments was assessed in mice bearing genetically targeted deletions (or crippling mutations) of the various receptors. In male mice, mutations in neither ER $\alpha$ nor AR altered the response of KiSS-1 to testosterone in either the Arc or AVPV (Smith et al. 2005b). Thus, in the male with a congenital absence of either $E R \alpha$ or $A R$, the remaining receptor can fully compensate for the lack of the other. This does not appear to be the case in the female. In the female mouse, targeted deletion of the ER $\alpha$ completely blocks the ability of estradiol to regulate the expression of KiSS1 in both the AVPV and Arc (Fig. 4), whereas a genetically targeted deletion of ER $\beta$ had no effect on the ability of estradiol to regulate KiSS-1 expression in either the Arc or AVPV (Smith et al. 2005a). Thus, in the female, it appears that $E R \alpha$ plays a critical role in the regulation of KiSS-1 in both the AVPV and Arc, and ER $\beta$ plays no clearly discernible role in this process.

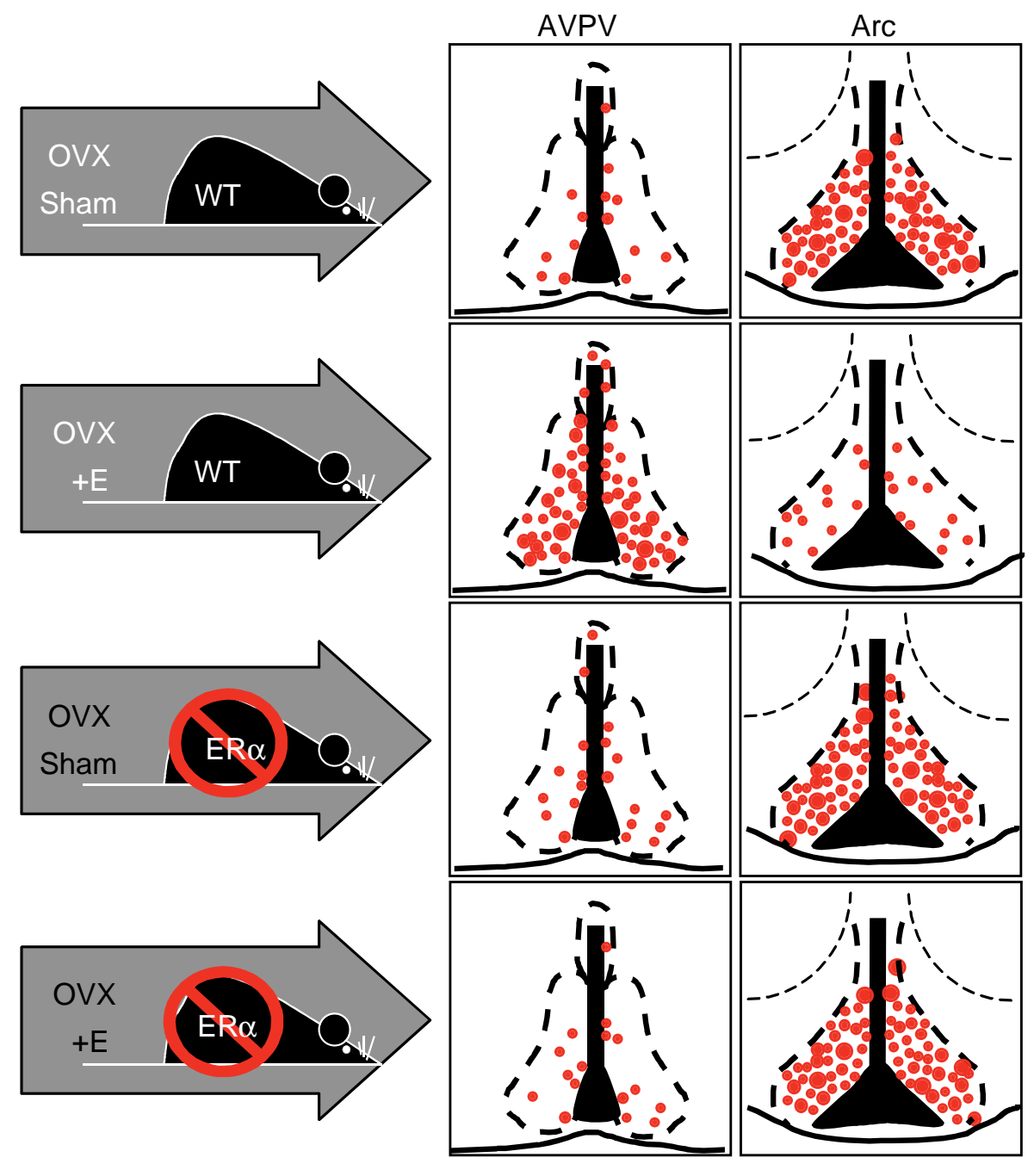

Figure 4 The effect of estradiol on KiSS-1 mRNA expression depends on estrogen receptor alpha (ER $\alpha)$. In wild-type (WT) control mice after ovariectomy, the expression of KiSS-1 mRNA (red dots) is reduced in the anteroventral periventricular nucleus (AVPV) and elevated in the arcuate nucleus (Arc). This pattern is reversed with estradiol (E) replacement; that is, KiSS-1 mRNA is elevated in the AVPV and reduced in the Arc. In ER $\alpha$ knockout mice, E treatment has no effect on the expression of KiSS-1 mRNA in either the AVPV or Arc. 


\section{Does kisspeptin-GPR54-GnRH signaling trigger puberty?}

Animals with disabling mutations and targeted deletions of GPR54 fail to progress through puberty, as a result of hypogonadotropic hypogonadism (Funes et al. 2003, Seminara et al. 2003). This would argue that activation of GPR54 is at least 'permissive' for the onset and maintenance of GnRH and LH secretion; however, the precise role that kisspeptinGPR54-GnRH signaling plays in gating the onset of puberty is unclear. Activation of $\mathrm{GnRH}$ neurons is the key event that initiates the onset of puberty (Ojeda \& Urbanski 1994, Plant 1994), but the nature of this 'trigger' remains to be identified. Kisspeptin-GPR54 signaling is a plausible candidate. Matsui et al. (2004) demonstrated that peripheral administration of kisspeptin to prepubertal, 25-day-old female rats stimulates LH secretion and induces ovulation in the rat. Shortly thereafter, Navarro et al. (2004a, 2004b) demonstrated a similar effect of kisspeptin on LH secretion in prepubertal male rats and showed that kisspeptins could advance the timing of vaginal opening in females. If kisspeptins trigger puberty onset, one would expect to see an increase in KiSS-1 mRNA and/or GPR54 mRNA expression during this time. Using semiquantitative RT-PCR on hypothalamic fragments, Navarro et al. (2004a) showed that this is indeed the case in both male and female rats. In the male mouse, KiSS-1 mRNA expression, measured by in situ hybridization, is stable in the Arc across pubertal development but increases significantly in the AVPV (Han et al. 2005), a region directly implicated in the activation of
GnRH neurons (Herbison 1998). Thus, kisspeptin-GPR54 signaling appears to be amplified at the time of puberty and could represent the proximate event that activates $\mathrm{GnRH}$ neurons and awakens the neuroendocrine reproductive axis at puberty.

The physiologic mechanisms that govern the onset of puberty differ between the rodent and primate (Ojeda \& Urbanski 1994, Plant 1994), yet recent evidence suggests that kisspeptin may also play a role in triggering the onset of puberty in the primate. First, central injections of kisspeptins stimulate LH in prepubertal, agonadal male monkeys, demonstrating that kisspeptin can override the central inhibition of $\mathrm{GnRH}$ secretion characteristic of the prepubertal primate (Shahab et al. 2005). Second, hypothalamic content of KiSS-1 mRNA increases across puberty in both the agonadal male and intact female monkey, suggesting that increased production of kisspeptin could contribute to activating the neuroendocrine reproductive axis at puberty in this primate species (Shahab et al. 2005). Hypothalamic levels of GPR54 mRNA also increase as a function of pubertal maturation - but only in the intact female - indicating that this is a steroid-dependent phenomenon and unlikely to be a centrally mediated 'triggering' event for puberty (Shahab et al. 2005).

The electrophysiologic response of $\mathrm{GnRH}$ neurons to kisspeptins appears to change dramatically over the course of puberty. With gramicidin-perforated patch recordings from brain slice preparations, approximately $30 \%$ of $\mathrm{GnRH}$ neurons responded to kisspeptin administration in prepubertal male GnRH-GFP transgenic mice,

\section{GnRH Neuron}

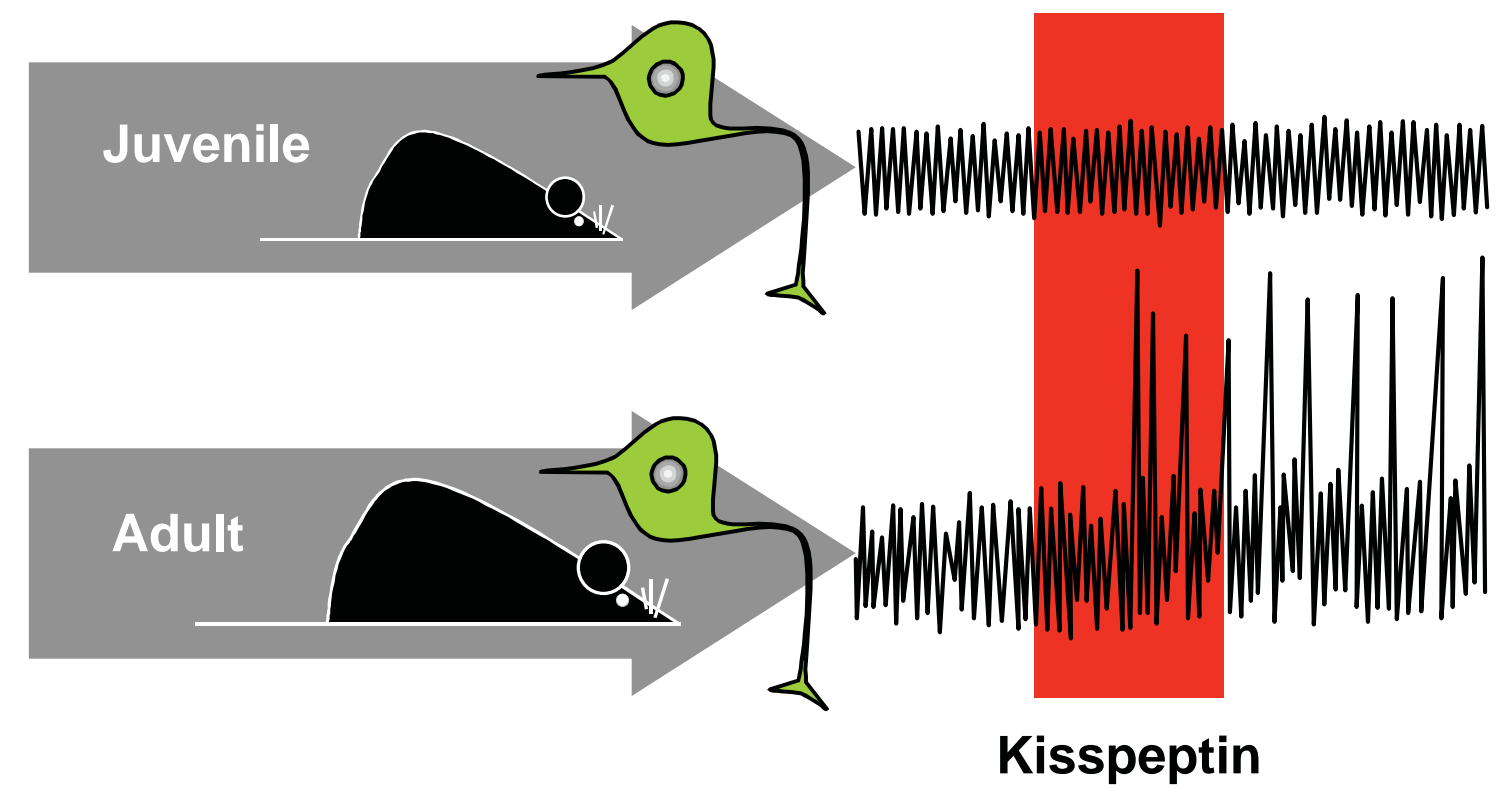

Figure 5 Possible role of kisspeptin in the onset of puberty. Recent observations suggest that GnRH neurons become increasingly responsive to kisspeptin as a function of pubertal maturation in the mouse. In this example, gramicidin-perforated patch recordings were used to assess the electrophysiologic response of GnRH neurons to central kisspeptin administration (red bar). 
whereas $90 \%$ of $\mathrm{GnRH}$ neurons from adult mice responded to the same dose of kisspeptins (Han et al. 2005) (Fig. 5). In addition, the excitatory effect of kisspeptin appears to directly activate $\mathrm{GnRH}$ neurons because the response remains in the presence of tetrodotoxin, and this is in direct agreement with nearly all GnRH neurons expressing GPR54 (Han et al. 2005). In parallel to this data, central injections of lower doses of kisspeptins (10-100 fmol) stimulate LH in adult, but not prepubertal, male mice (Han et al. 2005). Thus, it appears in the mouse that GnRH neurons become developmentally activated by kisspeptins over the course of puberty (Fig. 5). Just how this phenomenon occurs remains uncertain. One would expect that the expression of GPR54 in GnRH neurons would increase to facilitate the increased kisspeptin response, but this does not appear to be the case. Levels of GPR54 mRNA in GPR54 neurons are almost identical between prepubertal and postpubertal male mice (Han et al. 2005). Thus, it appears likely that kisspeptin participates in the pubertal renaissance of $\mathrm{GnRH}$ secretion in the primate. However, the newly refined question remains - what awakens the kisspeptin/GPR54/GnRH circuitry at the time of puberty? Only time and further research will tell.

In summary, the past 2 years has brought kisspeptin and its receptor GPR54 to the forefront of the neuroendocrine control of the gonadotropin axis. A vast array of data in many species has clearly shown that kisspeptin is critically important to the release of $\mathrm{GnRH}$, and this stimulation appears to occur directly at the GnRH neuron. Furthermore, recent data suggest that kisspeptin-secreting neurons (those expressing KiSS-1 mRNA) are the longsought link between peripheral sex steroids and $\mathrm{GnRH}$ release, and it is these neurons in the Arc and AVPV that appear to be well placed for both negative and positive feedback control of GnRH. Finally, evidence is continually emerging that links kisspeptin-GPR54 signaling to the onset of puberty, and it is this question that is providing new and exciting challenges for the future.

\section{Acknowledgements}

The authors declare that there is no conflict of interest that would prejudice the impartiality of this scientific work.

\section{References}

Brailoiu GC, Dun SL, Ohsawa M, Yin D, Yang J, Chang JK, Brailoiu E \& Dun NJ 2005 KiSS-1 expression and metastin-like immunoreactivity in the rat brain. Journal of Comparative Neurology 481 314-329.

Canteras NS, Simerly RB \& Swanson LW 1994 Organization of projections from the ventromedial nucleus of the hypothalamus: a Phaseolus vulgaris-leucoagglutinin study in the rat. Journal of Comparative Neurology 348 41-79.

de Roux N, Genin E, Carel JC, Matsuda F, Chaussain JL \& Milgrom E 2003 Hypogonadotropic hypogonadism due to loss of function of the KiSS1-derived peptide receptor GPR54. PNAS 100 10972-10976.
Dhillo WS, Chaudhri OB, Patterson M, Thompson EL, Murphy KG Badman MK, McGowan BM, Amber V, Patel S, Ghatei MA \& Bloom SR 2005 Kisspeptin-54 stimulates the hypothalamicpituitary gonadal axis in human males. Journal of Clinical Endocrinology and Metabolism 90 6609-6615.

Funes S, Hedrick JA, Vassileva G, Markowitz L, Abbondanzo S, Golovko A, Yang S, Monsma FJ \& Gustafson EL 2003 The KiSS-1 receptor GPR54 is essential for the development of the murine reproductive system. Biochemical and Biophysical Research Communications 312 1357-1363.

Gottsch ML, Cunningham MJ, Smith JT, Popa SM, Acohido BV, Crowley WF, Seminara S, Clifton DK \& Steiner RA 2004 A role for kisspeptins in the regulation of gonadotropin secretion in the mouse. Endocrinology 145 4073-4077.

Gu GB \& Simerly RB 1997 Projections of the sexually dimorphic anteroventral periventricular nucleus in the female rat. Journal of Comparative Neurology 384 142-164.

Hagihara K, Hirata S, Osada T, Hirai M \& Kato J 1992 Distribution of cells containing progesterone receptor mRNA in the female rat di- and telencephalon: an in situ hybridization study. Brain Research. Molecular Brain Research 14 239-249.

Han SK, Gottsch ML, Lee KJ, Popa SM, Smith JT, Jakawich SK, Clifton DK, Steiner RA \& Herbison AE 2005 Activation of gonadotropin-releasing hormone neurons by kisspeptin as a neuroendocrine switch for the onset of puberty. Journal of Neuroscience $\mathbf{2 5}$ $11349-11356$.

Herbison AE 1998 Multimodal influence of estrogen upon gonadotropin-releasing hormone neurons. Endocrine Reviews 19 302-330.

Hrabovszky E, Shughrue PJ, Merchenthaler I, Hajszan T, Carpenter CD, Liposits M \& Petersen SL 2000 Detection of estrogen receptor-beta messenger ribonucleic acid and 125I-estrogen binding sites in luteinizing hormone-releasing hormone neurons of the rat brain. Endocrinology 141 3506-3509.

Hrabovszky E, Steinhauser A, Barabas K, Shughrue PJ, Petersen SL, Merchenthaler I \& Liposits Z 2001 Estrogen receptor-beta immunoreactivity in luteinizing hormone-releasing hormone neurons of the rat brain. Endocrinology 142 3261-3264.

Irwig MS, Fraley GS, Smith JT, Acohido BV, Popa SM, Cunningham MJ, Gottsch ML, Clifton DK \& Steiner RA 2004 Kisspeptin activation of gonadotropin releasing hormone neurons and regulation of KiSS-1 mRNA in the male rat. Neuroendocrinology 80 264-272.

Kinoshita M, Tsukamura H, Adachi S, Matsui H, Uenoyama Y, Iwata K, Yamada S, Inoue K, Ohtaki T, Matsumoto H \& Maeda KI 2005 Involvement of central metastin in the regulation of preovulatory LH surge and estrous cyclicity in female rats. Endocrinology 146 4431-4436.

Kotani M, Detheux M, Vandenbogaerde A, Communi D, Vanderwinden JM, Le Poul E, Brezillon S, Tyldesley R, Suarez-Huerta N, Vandeput F, Blanpain C, Schiffmann SN, Vassart G \& Parmentier M 2001 The metastasis suppressor gene KiSS-1 encodes kisspeptins, the natural ligands of the orphan G protein-coupled receptor GPR54. Journal of Biological Chemistry 27634631 -34636.

Lee DK, Nguyen T, $O^{\prime}$ Neill GP, Cheng R, Liu Y, Howard AD, Coulombe N, Tan CP, Tang-Nguyen AT, George SR \& O'Dowd BF 1999 Discovery of a receptor related to the galanin receptors. FEBS Letters 446 103-107.

Lee JH, Miele ME, Hicks DJ, Phillips KK, Trent JM, Weissman BE \& Welch DR 1996 KiSS-1, a novel human malignant melanoma metastasis-suppressor gene. Journal of the National Cancer Institute 88 1731-1737.

Matsui H, Takatsu Y, Kumano S, Matsumoto H \& Ohtaki T 2004 Peripheral administration of metastin induces marked gonadotropin release and ovulation in the rat. Biochemical and Biophysical Research Communications $320383-388$.

Messager S, Chatzidaki EE, Ma D, Hendrick AG, Zahn D, Dixon J, Thresher RR, Malinge I, Lomet D, Carlton MB, Colledge WH, Caraty A \& Aparicio SA 2005 Kisspeptin directly stimulates gonadotropin-releasing hormone release via $G$ protein-coupled receptor 54. PNAS 102 1761-1766. 
Muir AI, Chamberlain L, Elshourbagy NA, Michalovich D, Moore DJ, Calamari A, Szekeres PG, Sarau HM, Chambers JK, Murdock P, Steplewski K, Shabon U, Miller JE, Middleton SE, Darker JG, Larminie CG, Wilson S, Bergsma DJ, Emson P, Faull R, Philpott KL \& Harrison DC 2001 AXOR12, a novel human G protein-coupled receptor, activated by the peptide KiSS-1. Journal of Biological Chemistry 276 28969-28975.

Navarro VM, Castellano JM, Fernandez-Fernandez R, Barreiro ML, Roa J, Sanchez-Criado JE, Aguilar E, Dieguez C, Pinilla L \& TenaSempere M 2004a Developmental and hormonally regulated messenger ribonucleic acid expression of KiSS-1 and its putative receptor, GPR54, in rat hypothalamus and potent luteinizing hormone-releasing activity of KiSS-1 peptide. Endocrinology 145 4565-4574.

Navarro VM, Fernandez-Fernandez R, Castellano JM, Roa J, Mayen A, Barreiro ML, Gaytan F, Aguilar E, Pinilla L, Dieguez C \& TenaSempere M 2004b Advanced vaginal opening and precocious activation of the reproductive axis by KiSS-1 peptide, the endogenous ligand of GPR54. Journal of Physiology 561 379-386.

Navarro VM, Castellano JM, Fernandez-Fernandez R, Tovar S, Roa J, Mayen A, Barreiro ML, Casanueva FF, Aguilar E, Dieguez C, Pinilla L \& Tena-Sempere M 2005a Effects of KiSS-1 peptide, the natural ligand of GPR54, on follicle-stimulating hormone secretion in the rat. Endocrinology 146 1689-1697.

Navarro VM, Castellano JM, Fernandez-Fernandez R, Tovar S, Roa J, Mayen A, Nogueiras R, Vazquez MJ, Barreiro ML, Magni P, Aguilar E, Dieguez C, Pinilla L \& Tena-Sempere M 2005b Characterization of the potent luteinizing hormone-releasing activity of KiSS-1 peptide, the natural ligand of GPR54. Endocrinology 146 156-163.

Ohtaki T, Shintani Y, Honda S, Matsumoto H, Hori A, Kanehashi K, Terao Y, Kumano S, Takatsu Y, Masuda Y, Ishibashi $Y$, Watanabe T, Asada M, Yamada T, Suenaga M, Kitada C, Usuki S, Kurokawa T, Onda H, Nishimura O \& Fujino M 2001 Metastasis suppressor gene KiSS-1 encodes peptide ligand of a G-protein-coupled receptor. Nature 411 613-617.

Ojeda SR \& Urbanski HF 1994 Puberty in the rat. In Physiology of Reproduction, 2nd edn, pp 363-409. Eds E Knobil \& JD Neill. New York: Raven Press.

Parhar IS, Ogawa S \& Sakuma Y 2004 Laser-captured single digoxigenin-labeled neurons of gonadotropin-releasing hormone types reveal a novel G protein-coupled receptor (Gpr54) during maturation in cichlid fish. Endocrinology 145 3613-3618.

Plant TM 1994 Puberty in primates. In Physiology of Reproduction, 2nd edn, pp 453-485. Eds E Knobil \& JD Neill. New York: Raven Press.

Plant TM, Ramaswamy S \& Dipietro MJ 2006 Repetitive activation of hypothalamic GPR54 with intravenous pulses of kisspeptin in the juvenile monkey (Macaca mulatta) elicits a sustained train of GnRH discharges. Endocrinology 147 1007-1013.
Saitoh Y, Silverman AJ \& Gibson MJ 1991 Effects of N-methyl-D,Laspartic acid on luteinizing hormone secretion in normal mice and in hypogonadal mice with fetal preoptic area implants. Endocrinology $1282432-2440$.

Seminara SB, Messager S, Chatzidaki EE, Thresher RR, Acierno JS Jr, Shagoury JK, Bo-Abbas Y, Kuohung W, Schwinof KM, Hendrick AG, Zahn D, Dixon J, Kaiser UB, Slaugenhaupt SA, Gusella JF, O'Rahilly S, Carlton MBL, Crowley WF, Aparicio AJR \& Colledge WH 2003 The GPR54 gene as a regulator of puberty. New England Journal of Medicine 349 1614-1627.

Shahab M, Mastronardi C, Seminara SB, Crowley WF, Ojeda SR \& Plant TM 2005 Increased hypothalamic GPR54 signaling: a potential mechanism for initiation of puberty in primates. PNAS 102 2129-2134.

Shughrue PJ, Lane MV \& Merchenthaler I 1997 Comparative distribution of estrogen receptor-alpha and -beta mRNA in the rat central nervous system. Journal of Comparative Neurology 388 507-525.

Simerly RB 1998 Organization and regulation of sexually dimorphic neuroendocrine pathways. Behaviour and Brain Research 92 195-203.

Simerly RB, Chang C, Muramatsu M \& Swanson LW 1990 Distribution of androgen and estrogen receptor mRNA-containing cells in the rat brain: an in situ hybridization study. Journal of Comparative Neurology 294 76-95.

Simonian SX, Spratt DP \& Herbison AE 1999 Identification and characterization of estrogen receptor alpha-containing neurons projecting to the vicinity of the gonadotropin-releasing hormone perikarya in the rostral preoptic area of the rat. Journal of Comparative Neurology 411 346-358.

Smith JT, Cunningham MJ, Rissman EF, Clifton DK \& Steiner RA 2005a Regulation of Kiss1 gene expression in the brain of the female mouse. Endocrinology 146 3686-3692.

Smith JT, Dungan HM, Stoll EA, Gottsch ML, Braun RE, Eacker SM, Clifton DK \& Steiner RA 2005b Differential regulation of KiSS-1 mRNA expression by sex steroids in the brain of the male mouse. Endocrinology 146 2976-2984.

Thompson EL, Patterson M, Murphy KG, Smith KL, Dhillo WS, Todd JF, Ghatei MA \& Bloom SR 2004 Central and peripheral administration of kisspeptin-10 stimulates the hypothalamic-pituitary-gonadal axis. Journal of Neuroendocrinology 16 850-858.

Received 19 October 2005

First decision 30 November 2005

Revised manuscript received 23 December 2005

Accepted 12 January 2006 